\title{
Universiteit
}

Leiden

The Netherlands

\section{FIS-dependent trans-activation of tRNA and rRNA operons of} Escherichia coli

Bosch, L.; Nilsson, L.; Vijgenboom, E.; Verbeek, H.

\section{Citation}

Bosch, L., Nilsson, L., Vijgenboom, E., \& Verbeek, H. (1990). FIS-dependent transactivation of tRNA and rRNA operons of Escherichia coli. Biochimica Et Biophysica Acta, 1050(1-3), 293-301. doi:10.1016/0167-4781(90)90184-4

Version: $\quad$ Publisher's Version

License: $\quad$ Licensed under Article 25fa Copyright Act/Law (Amendment Taverne)

Downloaded from: https://hdl.handle.net/1887/3239416

Note: To cite this publication please use the final published version (if applicable). 
BBAEXP 92147

\title{
FIS-dependent trans-activation of tRNA and rRNA operons of Escherichia coli
}

\author{
Leendert Bosch, Lars Nilsson *, Erik Vijgenboom and Hans Verbeek \\ Department of Biochemistry, Leiden University, Gorlaeus Laboratories, Leiden (The Netherlands)
}

(Received 16 May 1990)

Key words: Stable RNA operon; Trans-activation; FIS; EF-Tu; Transcription regulation; ( $E$. coli)

Two mechanisms controlling stable RNA synthesis have been described: growth rate-dependent control and stringent response. Although the mechanism underlying growth rate-dependent control is still a matter of dispute, this control is commonly assumed to operate through repression of transcription initiation of stable RNA operons. The same is true for the stringent response. Here we show that the cell utilizes an additional control system, operating through activation of the thr $U(t u f B)$ operon. This operon, the $t y r T$ and the $r m B$ operon share a common trans-activating protein that binds to cis-acting DNA regions upstream of the promoters of the two tRNA operons and of the P1 promoter of the $r m B$ operon. Conceivably, more stable RNA operons may be regulated by trans-activation. Both in vivo and in vitro experiments show that the Escherichia coli protein FIS (Factor for Inversion Stimulation) is involved in the trans-activation. This protein is known to stimulate the inversion of various DNA segments by binding to cis-acting recombinational enhancers and functions as a host factor for the bacteriophages $\mathrm{Mu}$ and Lambda.

\section{Introduction}

The polypeptide chain elongation factor EF-Tu and aminoacyl-tRNA are biological partners. During protein synthesis they form, together with GTP, a ternary complex that interacts with the ribosome-messenger RNA complex [1,2]. The association of EF-Tu - GTP and aminoacyl-tRNA is functionally highly significant. It protects the aminoacylester bond against hydrolysis [3], it enables correct positioning of aminoacyl-tRNA in the ribosomal A-site [4] and it contributes to the accuracy of the translational process [5-9].

The partnership of EF-Tu and tRNA also becomes apparent at the level of the genes specifying these two macromolecules. One of the two EF-Tu encoding genes ( $t u f B$ ) is cotranscribed with four different tRNA genes [10-16] (cf. Fig. 1). This gene organization in a mixed operon, specifying both stable and informational RNA, raises highly interesting questions concerning the gene regulation. The synthesis of some $60 \mathrm{tRNAs}$ and that of the rRNAs are coordinately controlled with respect to

\footnotetext{
* Present address: Department of Cell Biology, University of Stockholm, S-106 91 Stockholm, Sweden.

Correspondence: L. Bosch, Department of Biochemistry, Leiden University, Gorlaeus Laboratories, P.O. Box 9502, 2300 RA Leiden, The Netherlands.
}

growth rate $[17,18]$ and the stringent response $[19,20]$ except at very low growth rates. This suggests that the syntheses of tufB mRNA, tRNA, rRNA (and thus the ribosome) share at least some common regulation system. On the other hand a more detailed study of the regulation of the $\operatorname{thr} U($ tufB $)$ operon may shed new light on the control of stable RNA and ribosome synthesis. These expectations are borne out by the experiments described in the present paper.

Until recently, two mechanisms controlling stable RNA synthesis have been described: growth rate-dependent control and stringent response [21-23,24-26]. Growth rate-dependent control has been ascribed by Nomura and co-workers to feedback inhibition, exerted by vacant ribosomes produced in excess of the amount needed for protein synthesis [21-23]. Possibly, vacant ribosomes do not act directly but indirectly via the formation of ppGpp that accumulates under the condition of feedback inhibition [19]. Although the mechanism underlying growth rate-dependent control is still a matter of dispute [22,23], it is commonly assumed to operate through repression of transcription initiation of stable RNA operons. The same is true for the stringent response that is elicited when an aminoacylated tRNA becomes the limiting factor during protein synthesis [24]. Here we show that the cell utilizes an additional control system, operating through activation of the $\operatorname{thr} U(t u f B)$ operon. This operon, the $\operatorname{tyr} T$ and the $r r n B$ 
operon share a common trans-activating protein that binds to cis-acting DNA regions upstream of the promoters of the two tRNA operons and of the P1 promoter of the $r r n B$ operon. Conceivably, more stable RNA operons may be regulated by trans-activation. Both in vivo and in vitro experiments show that the $E$. coli protein FIS (Factor for Inversion Stimulation) is involved in the trans-activation. A burst of FIS-dependent stable RNA promoter activity is observed during outgrowth of stationary cultures in fresh medium and after a nutritional shift up. Repression and trans-activation of stable RNA operons create optimal conditions for fine tuning of this costly process. One of the functions of FIS is to allow very fast growth (Nilsson, L., unpublished data).

\section{Materials and Methods}

\section{Infection with bacteriophage $\mathrm{Mu}$}

Strains growing in the logarithmic phase in NY medium (per liter; $8 \mathrm{~g}$ Nutrient Broth, $5 \mathrm{~g}$ Yeast Extract, $8 \mathrm{~g} \mathrm{NaCl}, 2.5 \mathrm{mM} \mathrm{CaCl}, 10 \mathrm{mM} \mathrm{MgCl}{ }_{2}$ and the appropriate antibiotic) were infected at $A_{560}=0.25$ with $10^{8}$ phages $/ \mathrm{ml}$ for $20 \mathrm{~min}$ at $37^{\circ} \mathrm{C}$. Lysates of bacteriophage $\mathrm{Mu}$ (titer $10^{9} \mathrm{pfu}$ ) were prepared on a wild-type strain of $E$. coli and stored for no longer than two weeks at $4^{\circ} \mathrm{C}$. Infected cells were plated on NYplates containing $50 \mu \mathrm{g} / \mathrm{ml}$ kirromycin and $1.5 \mathrm{mM}$ EDTA. Plates were incubated at $37^{\circ} \mathrm{C}$ and kirromycin resistant colonies were screened for $\mathrm{Mu}$ immunity by crossstreaking single colonies through a line of a $\mathbf{M u}_{\text {clear }}$ lysate on NY plates. The integration of $\mathrm{Mu}$ in either tufA or tufB was confirmed by P1 transduction [28]. Bacteriophage $\mathrm{Mu}$ was generously provided by $\mathrm{Dr}$. N. Goosen.

\section{Protein isolation}

GDP-Sepharose affinity chromatography was performed as described by Jacobson and Rosenbusch with some minor modifications. Cells were resuspended in buffer $\mathrm{A}(\mathrm{Ac})$ (50 mM Tris- $\mathrm{HCl} \mathrm{pH} 8,10 \mathrm{mM} \mathrm{MgAc} c_{2}$, $175 \mathrm{mM} \mathrm{NaCl}, 6 \mathrm{mM} \beta$-mercaptoethanol, $100 \mu \mathrm{M}$ phenylmethylsulphonyl fluoride). Cell extracts were not fractionated with ammonium sulfate. FIS was kindly provided by Drs. C. Van Drunen and N. Goosen.

\footnotetext{
Band shift assay

${ }^{32} \mathrm{P}$-labeled DNA fragments and protein were incubated for 10 minutes at $37^{\circ} \mathrm{C}$ in a total volume of 20 $\mu 1$ containing: $10 \mathrm{mM}$ Tris- $\mathrm{HCl}$ (pH 7.8), $100 \mathrm{mM} \mathrm{KCl}$, $5 \mathrm{mM} \mathrm{MgCl}_{2}, 1 \mathrm{mM}$ EDTA, $100 \mu \mathrm{g} / \mathrm{ml}$ BSA and put on ice. Dye mix $(2 \mu 1,50 \%$ glycerol, $0.25 \%$ Bromophenol blue, $0.25 \%$ xylene cyanol) was added and the samples were loaded onto a $5 \%$ polyacrylamide gel (acrylamide : bisacrylamide equals $30: 1$ in $40 \mathrm{mM}$ Tris-acetate (pH 7.8), 2 mM EDTA). Gels were pre-run until the
}

conductivity was invariant. Electrophoresis was carried out at $14 \mathrm{~V} / \mathrm{cm}$ at room temperature, gels were dried and subjected to autoradiography.

\section{DNaseI footprinting}

The Bam HI-HaeIII fragment $(-176-+109)$ of pDS13.13 [29] was labeled with ${ }^{32} \mathrm{P}$ at the $5^{\prime}$ end of the Bam HI site $(-176)$ and incubated with the FIS containing EF-Tu - GDP preparation as described for the band shift assay. After a $10 \mathrm{~min}$ incubation DNaseI was added to a final concentration of $1.2 \mu \mathrm{g} / \mathrm{ml}$ and incubation was continued at $30^{\circ} \mathrm{C}$ for $60 \mathrm{~s}$. Reactions were stopped by the addition of $30 \mu 1$ ice-cold $0.5 \mathrm{M}$ sodium acetate, $0.15 \mu \mathrm{g} / \mu 1 \mathrm{tRNA}, 33 \mathrm{mM}$ EDTA, phenol/chloroform extraction and precipitation with ethanol. Pellets were washed with $70 \%$ ethanol and resuspended in $80 \%(\mathrm{v} / \mathrm{v})$ formamide, $0.1 \%$ xylene cyanol, $0.1 \%$ Bromophenol blue. Samples were heated for $2 \mathrm{~min}$ at $95^{\circ} \mathrm{C}$ and analyzed by electrophoresis on a $12 \%$ polyacrylamide gel containing $7 \mathrm{M}$ urea, $89 \mathrm{mM}$ boric acid and 2 mM EDTA.

\section{Galactokinase assay}

Galactokinase activities and plasmid copy numbers were determined according to Adams and Hatfield [30] with some modifications as described by Van Delft et al. [29]. The strains used for the in vivo measurements of the transcriptional activity are: $\mathrm{MC1000}(\Delta$ lac X74 (acIPOZY), ara D139, $\Delta$ ara-leu 7697 (ara ABOC, leu), galU, galK, strA) and MC1000-FIS 767 (as MC1000 with fis :: $\operatorname{Kan}^{\circledR}$ ). The activities (pmol phosphogalactose $/($ fmol plasmid $\times$ min) ) are expressed as percentage of the activities in $\mathrm{FIS}^{+} \mathrm{UAS}^{+}$cells at time zero.

\section{Results}

As mentioned in the Introduction the $\operatorname{thr} U(\operatorname{tuf} B)$ operon is a dual function operon that is transcribed into stable RNA and informational RNA [15]. As such it differs from the str operon that harbours the other EF-Tu encoding gene tufA and in addition the genes for EF-G and the two ribosomal proteins $\mathrm{S} 12$ and $\mathrm{S} 7$ [31,32] (cf. Fig. 1). The str operon thus has the characteristics of an $r$ protein operon. Experiments by Van Delft et al. [33], who fused various regions of the $t h r U(t u f B)$ operon to a part of the lac operon, demonstrated that transcription initiation at the promoter of the $\operatorname{thr} U(\operatorname{tufB})$ operon increased with the growth rate. In this respect, it thus resembles a true stable RNA operon. Similar fusion experiments with the str operon (Verbeek, H., unpublished data) revealed that the activities of the primary and secondary promoter of this operon are growth rate independent like the activities of other r-protein operon promoters.

The thr $U(t u f B)$ operon also resembles some tRNA operons and the rRNA operon $r r n B$ in another way. As 


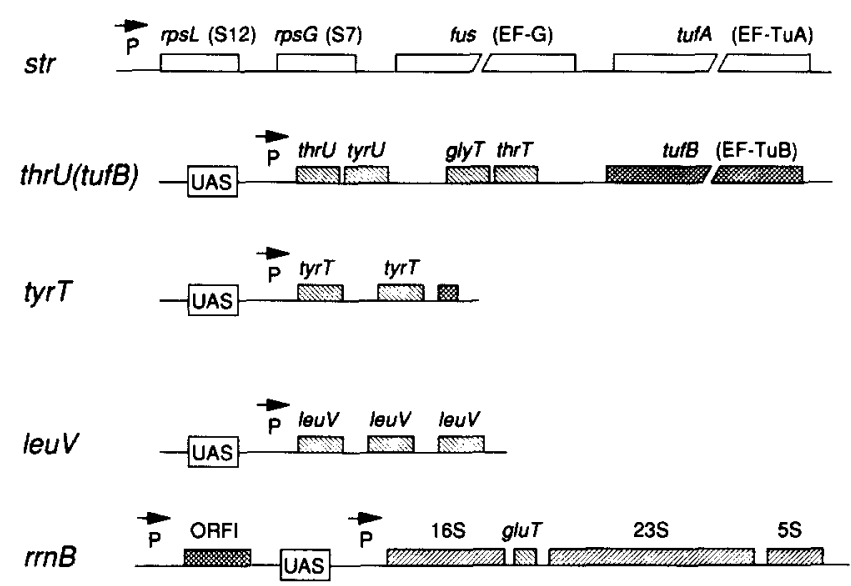

Fig. 1. The str operon and four stable RNA operons with upstream activator sequences (not drawn to scale).

illustrated in Fig. 1, the promoters of these operons are preceded by cis-acting regions, deletion of which reduces transcription some ten to twenty fold $[34,35,39,36]$. Although rRNA genes and most tRNA genes are highly expressed during exponential growth accounting for more than $50 \%$ of the total cellular transcripts, their promoters do not optimally fit the consensus -10 and -35 sequence $[23,37]$. This suggests that the activities of these promoters can be enhanced by virtue of a trans-activating protein, binding to the cis-acting region upstream of the promoter (called Upstream Activator Sequence or UAS). During a more detailed study of tuf gene expression a trans-activating protein controlling the $\operatorname{thr}(t u f B)$ operon was found (see below).

\section{What is the basis for tuf gene duplication?}

The 'raison d'être' of two tuf genes on the chromosome of a great number of gram negative bacteria is not well understood. Are both genes essential for bacterial growth? We have approached this question by selective inactivation of either gene. To this aim we utilized $E$. coli mutants altered in one or both tuf genes. Isolation of these mutants was facilitated by the finding of Parmeggiani and coworkers [38] that EF-Tu is the target of the antibiotic kirromycin, which binds to the factor protein in a 1:1 molar ratio. As a result of this binding EF-Tu.GDP sticks to the ribosome during elongation and protein synthesis is inhibited. This inhibition is very effective,since the ribosome becomes immobilized on the mRNA and blocks all ribosomes in its trail. Phenotypic expression of kirromycin resistance therefore requires both tuf genes to be altered and the wild-type allele is dominant over the mutated allele conferring resistance to the antibiotic [for a review see Ref. 39]. As can be seen in Table I, strain PM 816 shows such a dominance of a wild type tufB over a kirromycin-resistant tufA and strain EV 102 a dominance of a wild-type tufA over a kirromycin-resistant tufB. Selective inactivation of one of the tuf genes was
TABLE I

Escherichia coli K12 mutants altered in tufA and/or tufB

\begin{tabular}{|c|c|c|c|c|}
\hline \multirow[t]{2}{*}{ Strain } & \multirow[t]{2}{*}{ Genotype $^{a}$} & \multicolumn{2}{|c|}{ tuf gene products } & \multirow{2}{*}{$\begin{array}{l}\text { Kirro- } \\
\text { mycin- } \\
\text { resistan }\end{array}$} \\
\hline & & EF-TuA & EF-TuB & \\
\hline LBE 2021 & tufA tufB & $\begin{array}{l}\text { Ala-375 } \\
\rightarrow \text { Thr }\end{array}$ & $\begin{array}{l}\text { Gly-222 } \\
\rightarrow \text { Asp }\end{array}$ & yes \\
\hline PM816 & $\operatorname{tufA}$ & $\begin{array}{l}\text { Ala-375 } \\
\quad \rightarrow \mathrm{Thr}\end{array}$ & wild type & no \\
\hline EV 102 & $t u f B$ & wild type & $\begin{array}{c}\text { Ala-375 } \\
\quad \rightarrow \text { Thr }\end{array}$ & no \\
\hline PM 8161 & $\begin{array}{l}\text { tufA } \\
\quad \text { tuf } B::(\mathbf{M u})\end{array}$ & $\begin{array}{l}\text { Ala-375 } \\
\rightarrow \mathrm{Thr}\end{array}$ & not present & yes \\
\hline PM 505 & tufB : : (Mu) & wild type & not present & no \\
\hline
\end{tabular}

" For further details see Refs. 56, 57, 40, 42, 43.

attempted by inserting bacteriophage $\mathrm{Mu}$ into the wildtype gene of either of these two strains. After $\mathrm{Mu}$ infection, colony formation was studied on plates containing kirromycin and the kirromycin-resistant cells were screened for $\mathrm{Mu}$ immunity. Mu insertion into $t u f B$ of strain PM 816 thus yielded the kirromycin-resistant strain PM 8161 (cf. Table I) which leads to the conclusion that $t u f B$ is dispensable for growth, at least under our laboratory conditions $[40,41]$. Insertion into tuf $A$ of strain EV 102, however, is incompatible with growth $[40,42,43]$. The tufA defect can be complemented by plasmid-borne tufA. This is illustrated in Table II, line 3. The plasmid $\mathrm{pGp} 82^{\mathrm{R}}$ carries a kirromycin-resistant tufA behind a fusion promoter. Kirromycin-resistant colonies appear $18 \mathrm{~h}$ after $\mathrm{Mu}$ infection with the same frequency of $\mathrm{Mu}$ insertion, just as they do after infection of PM 816. Complementation with the plasmid $\mathrm{pTuB}_{10}^{\mathrm{R}}$, harbouring the entire $\operatorname{thr} U(t u f B)$ operon with a kirromycin-resistant $t u f B$, is much less effective (Table II, line 4). Colony formation is strongly retarded $(7 \mathrm{~h}$ delay) and the frequency of $\mathrm{Mu}$ insertion is lowered at least one order of magnitude. The differential complementation is not due to a difference in function of the tuf gene products EF-TuA and EF-TuB, which differ in their C-terminal residue. EF-TuA has a glycine, EF-TuB a serine in the C-terminal position (residue 393 ). This

\section{TABLE II}

Inactivation of the chromosomal tufB of strain PM 816 or the chromosomal tufA of strain EV 102 by bacteriophage $\mathrm{Mu}$

\begin{tabular}{lll}
\hline Strain & Plasmid & $\begin{array}{l}\text { Delay in } \\
\text { colony appearance }\end{array}$ \\
\hline 1 PM 816 & & $0 \mathrm{~h}$ \\
2 EV 102 & & $\infty$ \\
3 EV 102 & pGp82 $^{\mathrm{R}}$ & $0 \mathrm{~h}$ \\
4 EV 102 & pTUB $_{10}^{\mathrm{R}}$ & $7 \mathrm{~h}$ \\
5 EV 102 & pGp82 $^{\mathrm{R}}$ Gly-393 $\rightarrow$ Ser) & $0 \mathrm{~h}$ \\
6 EV 102 & pTUB $_{10}^{\mathrm{R}}($ Ser-393 $\rightarrow$ Gly) & $7 \mathrm{~h}$ \\
\hline
\end{tabular}




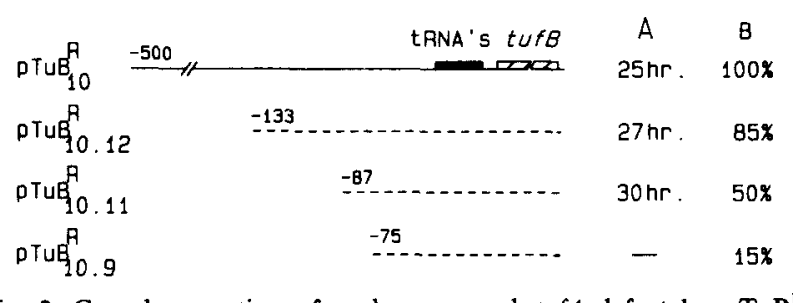

Fig. 2. Complementation of a chromosomal tufA defect by $\mathrm{pTuB}_{10}^{\mathrm{R}}$ and its deletion derivatives. (A) The appearance of kirromycin resistant colonies of EV102 transformants after inactivation of tufA by Mu (compare Table II). (B) Transcription activities of the plasmidborne $\operatorname{thr} U(t u f B)$ operon [29].

was demonstrated by site-directed mutagenesis of plasmid-borne tufA, altering the Gly-393 into Ser-393. As is evident from Table II, line 5, complementation by the mutated plasmid remains equally effective. It may be realized that the transformant cells now produce EF-TuB as the sole EF-Tu species. Conversely, site-directed mutagenesis of $\mathrm{pTuB}_{10}^{\mathrm{R}}$, altering Ser-393 into Gly-393, does not improve the poor complementation of the tufA defect, despite the fact that the tuf product encoded by the plasmid is now EF-TuA. Apparently, the difference in complementation is due to a difference in tuf gene expression rather than to a difference in function of the two tuf products.

The results described above can be interpreted by an inadequate expression of the chromosomal $\operatorname{thr} U(t u f B)$ operon in the absence of a functioning chromosomal tufA [42]. Complementation by plasmid-borne thrU ( tufB) does occur due to the multiple plasmid copies yielding tuf gene products just sufficient to permit delayed colony formation. Further delay occurs upon down-modulation of the plasmid-borne $\operatorname{thr} U(t u f B)$ operon by deleting portions of its UAS. As is illustrated in Fig. 2, the delay increases when transcription of the complementing plasmid decreases. No colonies are detected any more when transcription has dropped to 15\%. Apparently, the total expression of chromosomeand plasmid-borne tuf genes has then dropped below the level compatible with growth. Apparently, the expression of the thrU(tufB) operon depends on a tuf gene product and thus on EF-Tu. This dependence may be direct, EF-Tu being the trans-activating protein that binds to the cis-acting UAS (see above) or indirect, EF-Tu being required for the synthesis of an unknown trans-activating factor.

In search for the trans-activator of the thrU(tufB) operon A direct involvement of EF-Tu in trans-activation of the $t h r U(t u f B)$ operon was suggested by the finding of Vijgenboom et al. [44] that incubation of EF-Tu - GDP, obtained by affinity chromatography on GDP-Sepharose and about $95 \%$ pure, with various DNA fragments of the UAS (Fig. 3) results in the formation of three protein-DNA complexes. These complexes can be detected with the electrophoretic retardation technic using fragments 13 and 12 . Fragment 11, however, which is 46 bp shorter, forms one protein-DNA complex only and fragment 9 , only 12 bp shorter is devoid of any binding activity. As can be seen in Fig. 3, the loss of in vitro binding upon shortening the fragments corresponds with the fall in transcription activity observed in vivo upon deleting the UAS of the operon. The sharpest drop is seen when the deletion is extended from position -87 to -75 which reduces the number of protein-DNA complexes from one to zero. This correspondence of the in vivo and in vitro data strongly suggests that the protein/DNA interaction results in trans-activation of the operon and that the EF-Tu - GDP preparation used here contains the trans-activator. Moreover, in vitro transcription of the plasmid-borne $\operatorname{thr} U(\operatorname{tuf} B)$ was found to be stimulated by this preparation [27]. In accordance with a direct involvement of EF-Tu was the observation that kirromycin inhibits complex formation [44].

Purification of the EF-Tu - GDP preparation to homogeneity, however, revealed that a protein cofractionating with EF-Tu.GDP on GDP-Sepharose, rather than EF-Tu - GDP itself is binding to the DNA. This protein, which appeared rather heat stable, can be
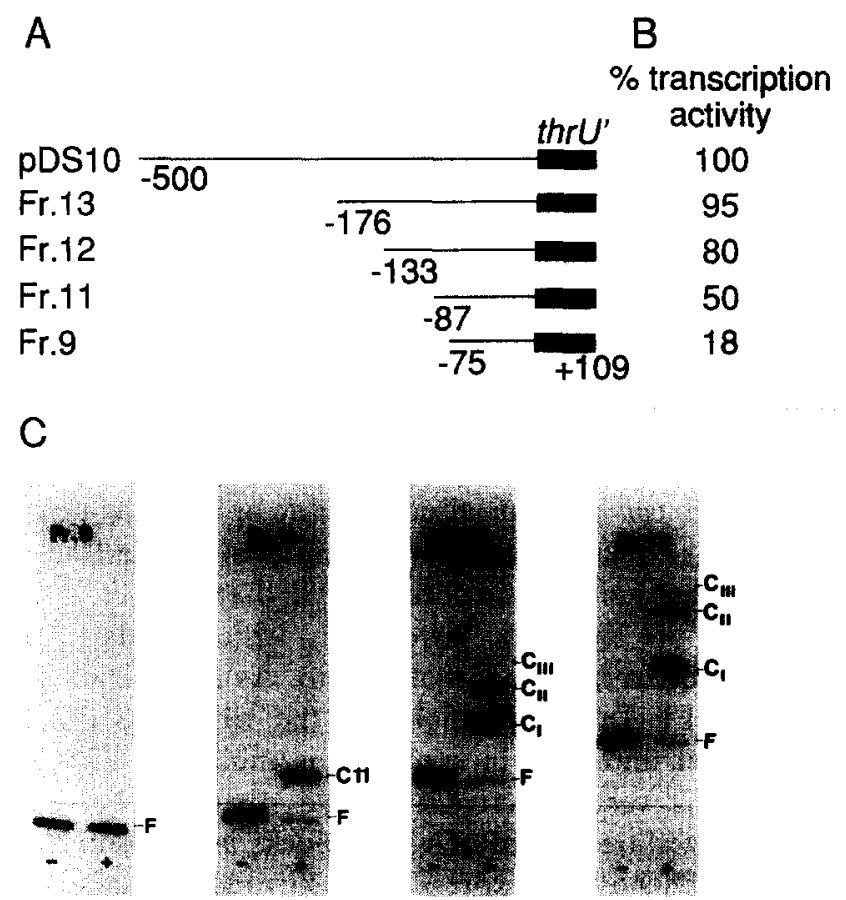

Fig. 3. The nucleotide sequences (A) upstream of the thr $U(t u f B)$ promoter, acting in cis on transcription in vivo (B) and involved in specific protein binding in vitro (C). Transcription activities of cells, transformed with pDS10 derivatives harboring deletions in the region upstream of the promoter of $t h r U(t u f B)^{\prime} g a l K$ operon fusion, were determined by measuring the galactokinase activities. Panel $\mathrm{C}$ shows the electrophoretic retardation of the protein-DNA complexes TCH, CI, CII and CHI) as compared with the electrophoretie rate of free DNA (F) [44]. 
separated from EF-Tu - GDP by fractionation on a monoQ column [27]. More detailed studies of the 95\% pure EF-Tu - GDP preparation brought to light a number of properties that led to the identification of the DNA binding protein.

By varying the amounts of DNA and protein it was shown that the three protein-DNA complexes contain one and the same protein. These studies also enabled determination of the dissociation constants for these complexes. A $K_{\mathrm{d}}$ in the nanomolar range was found for $\mathrm{C} 1$ (cf. Fig. 3), $K_{\mathrm{d}}$ values for $\mathrm{C} 2$ and $\mathrm{C} 3$ are approx. one order of magnitude lower [27].

DNase footprinting (Fig. 4) of DNA fragment 13 $(-176$ to +109$)$ complexed with the protein revealed two binding regions extending from -48 to -81 and from -118 to -131 . Further footprinting experiments are needed to elucidate the binding sites occupied in complex I to III (cf. Fig. 3). Three enhanced cleavage sites (indicated with arrows) are located in the binding areas. The enhanced accessibility to DNaseI suggests that protein binding causes bending of the DNA, analogous to the reported relation between DNA-loop formation and enhanced DNaseI cleavage [45]. In fact electrophoretic studies of DNA fragments derived from the cis-acting regions upstream of $t y r T$ [46] and $r r n B$ [36] indicate that these AT-rich elements can adopt unusual physical conformations, possibly involving kinking or bending of the DNA helix. Fragment 13 of the $\operatorname{thr} U(t u f B)$ operon also shows such an anomalous behaviour [42]. This suggests that bending of the DNA enables binding of the trans-activator and this binding enhances the bending. The properties of the protein binding to the UAS of $\operatorname{thr} U(\operatorname{tufB})$, appeared to be very similar to those of the $E$. coli protein FIS.

FIS is a heat-stable protein of 98 amino acids $[47,49]$ that plays a role in site-specific recombination, mediating the inversion of DNA segments by binding to cis-acting recombinational enhancers [48-53]. In doing so it induces the bending of enhancer DNA and the bending is an essential step for recombinational activity. Hübner and Arber [54] compiled a consensus for FIS binding sites by comparing a number of recombinational enhancers (Fig. 5). The two regions protected against DNase 1 shown in Fig. 4 each contain a sequence of $15 \mathrm{bp}$ centering around position -71 and -123 that matches this consensus. That FIS binds to the UAS of the $\operatorname{thr} U(t u f B)$ operon was demonstrated by incubating fragment 13 with purified FIS (Fig. 6). Band shifts [27] reveal three protein/DNA complexes similar to the complexes presented in Fig. 3. Also in vivo FIS interacts with the UAS as is illustrated in Fig. 7. In these experiments the plasmid-borne operon fusion thrU(tufB )'galK was used to study promoter activity in $\mathrm{fis}^{+}$and $\mathrm{fis}^{-}$cells during a normal bacterial growth cycle (Ref. 27 and Nilsson, L., unpublished data). Immediately after diluting a stationary culture in fresh

\section{4}

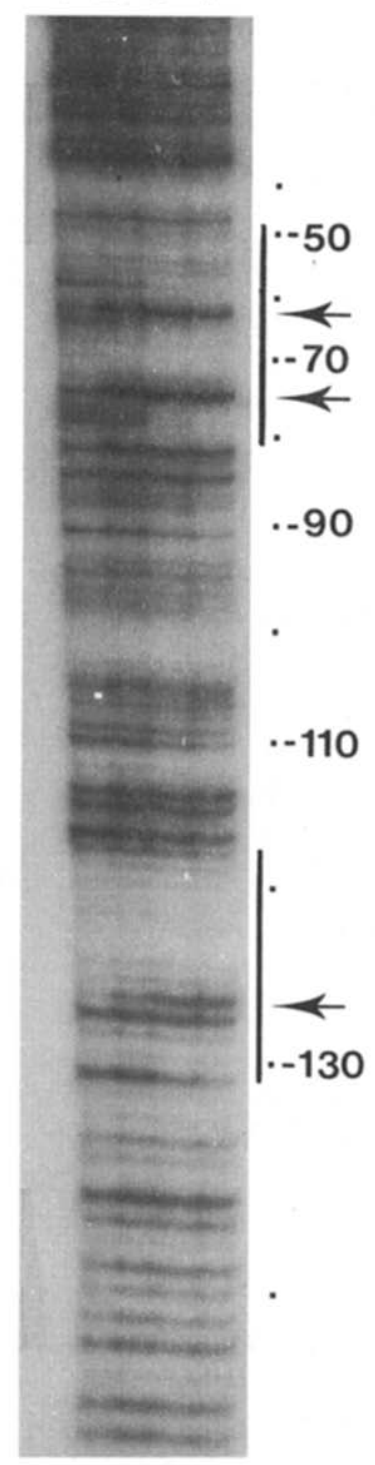

Fig. 4. DNaseI footprinting of a fragment $(-176-+109)$ derived from the promoter upstream region of the $\operatorname{thr} U(t u f B)$ operon. complexed with the FIS containing EF-Tu.GDP preparation. Protected regions, -48 to -81 and -118 to -131 , are indicated with a solid line and the arrows point at the enhanced cleavage sites, A $(-63), T$ $(-75)$ and $G(-127)$. The numbering of the nucleotides is with respect to the transcription start site. Lane 1 is without and lane 2 to 4 with increasing amounts of the protein preparation. In lane 4 sufficient protein is added for the formation of all three complexes (compare Fig. 3C).

medium galactokinase activity of the cells rises steeply, reflecting a burst of promoter activity when the UAS of the reporting operon fusion is intact (Fig. 7A). This burst is mainly due to trans-activation, since the increase in galactokinase activity is much smaller when

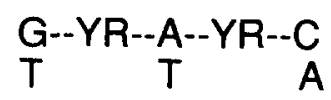

Fig. 5. FIS binding site consensus [54]. 


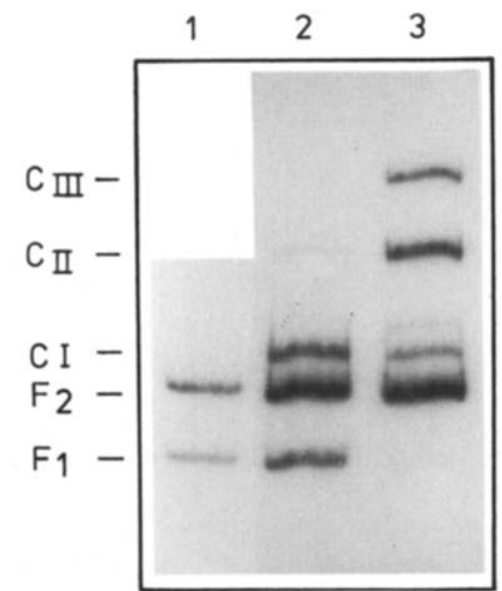

Fig. 6. Complex formation of FIS with the UAS fragment $\left(-176_{-}+\right.$ 109) of the $t h r U(t u f B)$ operon [27]. One fragment (F1) runs from position -176 to +109 , the other $(F 2)$ from +110 to +562 . Lane 1 , no FIS added. Lane 2, $1 \mathrm{ng}$ of FIS. Lane 3, $3 \mathrm{ng}$ of FIS.

the UAS is deleted. The small peak of galactokinase activity in so-called $\mathrm{UAS}^{-}$cells can be ascribed to relaxation of the repressive system. The burst in $\mathrm{UAS}^{+}$ cells is also dependent on FIS as can be concluded from the galactokinase activities in fis $^{-}$cells (Fig. 7B). In these cells the ratio of activities measured in the presence and absence of the UAS is constant throughout the entire growth cycle. This reflects a cis-effect of the UAS in the absence of FIS. In $\mathrm{fis}^{+}$cells, however, this ratio increases rapidly, showing that the trans-activation that takes effect immediately after reinitiation of growth, is FIS dependent.

The thrU(tufB), the tyrT and the $r r n B$ operons bind a common transactivating protein

Since stable RNA operons are coordinately expressed and all tRNA and rRNA operons are submitted to stringent response and growth rate-dependent control, the question arises whether trans-activation also
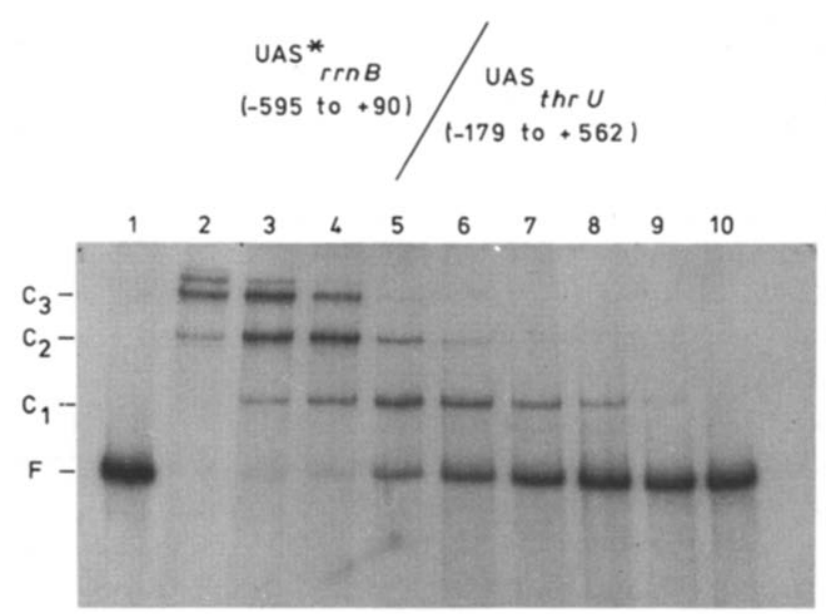

Fig. 8. UAS fragment labeled with ${ }^{32} \mathrm{P}$ of the $r r n B$ and unlabeled UAS fragments of the $t h r U(t u f B)$ operons compete for binding with the same protein. Lane 1: no protein added. Lanes 2-10: $0 \mathrm{nM}, 0.35$ $\mathrm{nM}, 0.7 \mathrm{nM}, 1.75 \mathrm{nM}, 3.5 \mathrm{nM}, 7 \mathrm{nM}, 17.5 \mathrm{nM}, 35 \mathrm{nM}$ and $70 \mathrm{nM}$, respectively, of the FIS containing EF-Tu.GDP preparation.

plays a role in this coordination. In an earlier stage of these investigations we addressed this question by asking whether or not the UASs of the $\operatorname{thr} U(\operatorname{tufB})$, the $\operatorname{tyr} T$ and the $r r n B$ (cf. Fig. 1) interact with the EF-Tu . GDP preparation. In vitro binding showing this to be the case, competition experiments were set up between DNA fragments of the UASs of the three operons. Fig. 8 shows such a competition between unlabeled UAS fragments of the thr $U($ tufB $)$ operon and labeled UAS fragments of $r r n B$. As can be seen, the labeled fragments are competed out for protein binding when the amount of unlabeled fragments is increased. Similar results were obtained in a competition between UAS fragments derived from the $\operatorname{tyr} T$ and the $\operatorname{thr} U(\operatorname{tufB})$ operons. Apparently, the three UASs bind the same protein. Since under the conditions of these experiments the proteinDNA complexes of the thrU(tufB) UAS contain one and the same protein (see above), we conclude that the
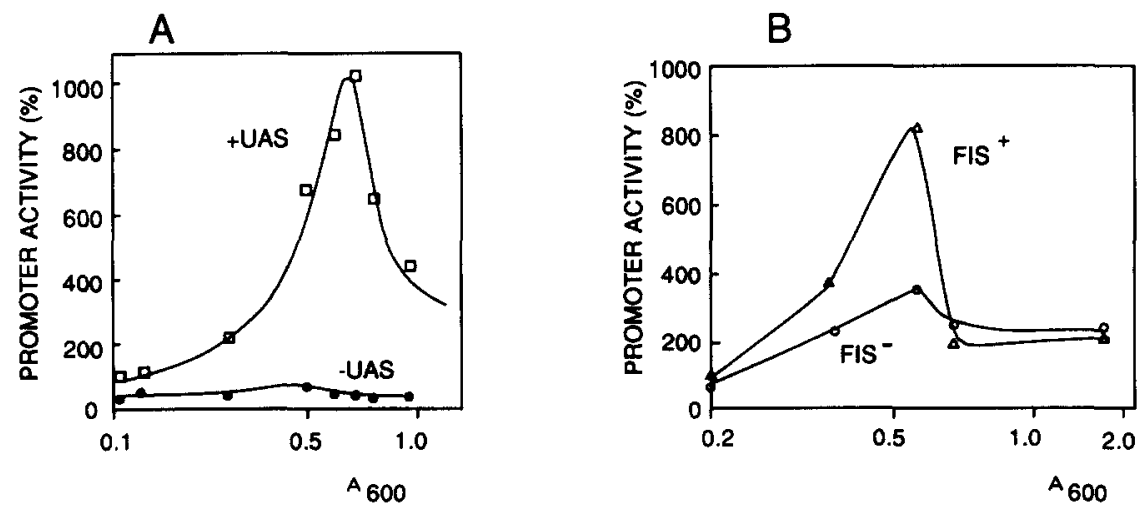

Fig. 7. Effects of FIS and the UAS on $t h r U(t u f B)$ promoter activity during the growth cycle of E. coli. Panel A, fis ${ }^{+}$cells (MC1000) transformed with pDS10 (UAS ${ }^{+}$) and the UAS deletion derivative. Panel B, $\mathrm{fis}^{+}$and $\mathrm{fis}^{-}$cells transformed with pDS10. Cells were grown overnight in LB medium, diluted to an $A_{600}$ of 0.2 and incubated at $37^{\circ} \mathrm{C}$. Galactokinase activities were determined after various periods of time and corrected for plasmid copy number. 
upstream regions of the three operons bind a common trans-activating protein which is FIS [27].

These results prompted us to examine nucleotide sequences upstream of other stable RNA operons for potential FIS binding sites using the consensus of Fig. 5. It turned out that five out of seven $r r n$ operons have a sequence of 15 nucleotides centering at position -71 that fully matches the consensus. The corresponding sequence of $r r n D$ has one deviating nucleotide and that of $r n E$ has two. Complete matching was also observed with sequences upstream of seven out of sixteen tRNA promoters although the sequences do not always center at -71 . One to two deviating nucleotides are present in sequences upstream of the other tRNA promoters. Based on the sequence information presently available it seems that operons may differ in the number of FIS binding sites upstream of their promoter. The data suggest that most, if not all stable RNA operons examined are submitted to FIS-dependent trans-activation but that the effect of FIS may differ from operon to operon (Verbeek, H. et al., unpublished data).

\section{FIS-dependent trans-activation in response to environ- mental signals}

The promoter activity of the $\operatorname{thr} U(\operatorname{tuf} B)$ operon shows large fluctuations during the bacterial growth cycle (cf. Fig. 7). After the burst in early $\log$ phase cells a precipitous drop is observed which may have two causes. Reinitiation of growth is accompanied by a rapid de novo synthesis of ribosomes which may lead to a temporary excess of ribosomes and to ribosome feedback and/or ppGpp formation. The plasmid-borne operon, lacking the UAS, confirms this with a drop in promoter activity. Large fluctuations in the cellular FIS level have also been observed. Using a FIS assay based on DNA binding activity, Thompson et al. [55] reported a 70-fold drop in FIS concentration during the transition from late-log phase to the stationary phase. Preliminary experiments in our laboratory, using western blotting, showed a rapid increase of FIS from a virtually zero level in stationary cells to high values soon after reinitiation of growth (Verbeek, H. et al., unpublished data).

The UAS-dependent burst in promoter activity varies with the composition of the medium. The peak height ratio in $\mathrm{UAS}^{+}$and $\mathrm{UAS}^{-}$cells is at least three times higher in cells growing in brain heart infusion medium than in cells growing in minimal medium. Response to environmental signals is also seen after a nutritional shift up. UAS $^{-}$cells do not respond to such a shift up with an increase of promoter activity, indicating that repressive control is not altered under these conditions (Nilsson, L. et al., unpublished data).

In mid-log phase, when cells grow under steady-state conditions, the nutritional quality of the medium determines the promoter activity by controling both trans-activation and repression. This can be concluded
TABLE III

Promoter activities of mid-log cells growing at various rates

\begin{tabular}{llll}
\hline $\begin{array}{l}\text { Growth rate } \\
\text { (doublings/h) }\end{array}$ & $\mathrm{UAS}^{+\mathrm{b}}$ & $\mathrm{UAS}^{-\mathrm{b}}$ & $\mathrm{UAS}^{+} / \mathrm{UAS}^{-}$ \\
\hline 0.9 & 9.0 & 1.5 & 6 \\
1.4 & 40.0 & 2.0 & 20 \\
1.6 & 50.0 & 2.4 & 21 \\
1.7 & 52.0 & 3.3 & 16 \\
2.0 & 62 & 4.2 & 15 \\
\hline
\end{tabular}

a Transformants (compare legend to Fig. 7) were grown overnight in different media and diluted to an $A_{600}$ of 0.1 .

${ }^{b}$ Galactokinase activities were determined at $A_{600}$ of 0.4 and expressed as pmol phosphogalactose/(fmol plasmid $\times$ min).

from an experiment in which $\mathrm{UAS}^{+}$and $\mathrm{UAS}^{-}$cells were grown in different media so that growth rate varied between 0.9 and 2.0 doublings/h (Table III). A linear relationship exists between the promoter activity of the $\operatorname{thr} U(\operatorname{tufB})$ operon and the growth rate of both $\mathrm{UAS}^{+}$and $\mathrm{UAS}^{-}$cells. In this range of growth rates the increase in promoter activity of $\mathrm{UAS}^{+}$cells exceeds that of UAS $^{-}$cells by a factor of 18 demonstrating that both trans-activation and repression regulate stable RNA synthesis. Upon enrichment of the medium, steady state growth is adjusted to higher rates by shifting the equilibrium between the two control systems in favour of trans-activation.

Stationary phase cells do not display any effect of FIS as can be concluded from Fig. 7A and B. Galactokinase activity in both $\mathrm{fis}^{+}$and $\mathrm{fis}^{-}$stationary cells is reduced by a factor of three upon deletion of the UAS. As mentioned above this reflects a cis-activation by this DNA element. No FIS could be detected by western blotting in these cells. A reduced relaxation of the repressive system becomes apparent when fis $^{-}$cells enter the stationary phase.

The data described above suggest that cells sense the nutritional quality of the medium and respond with altering the control by the two counteracting systems: trans-activation and repression of stable RNA synthesis. An attractive possibility is that the large variations of trans-activation in fis $^{+}$cells correlate with variations in cellular FIS concentration. If more experimental data corroborate this, it would mean that the regulation of de novo synthesis of FIS is a basic element of growth control.

\section{FIS and fast cellular growth}

High growth rates can be maintained for longer periods of time when cells grow under steady state conditions at very high dilution $(200-1000$ cells $/ \mathrm{ml})$. Growth rates of 3.4 and 2.3 doublings $/ \mathrm{h}$ are then recorded for $\mathrm{fis}^{+}$and $\mathrm{fis}^{-}$cells, respectively (Fig. 9). 


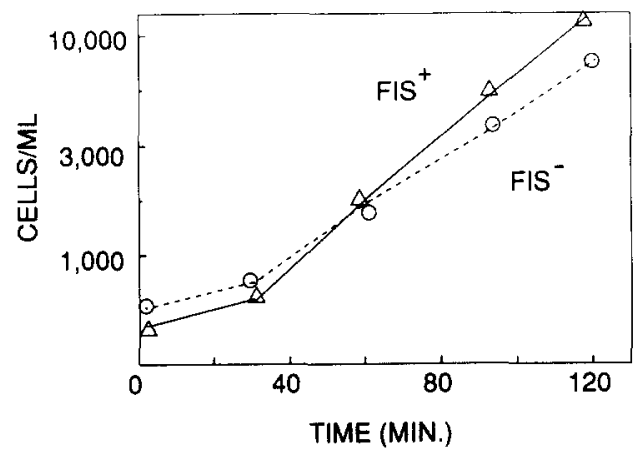

Fig. 9. Growth rates of $\mathrm{fis}^{+}$and $\mathrm{fis}^{-}$cells in highly diluted cultures. Mid-log cultures in LB medium were diluted to approx. 500 cells $/ \mathrm{ml}$. Cell concentrations were determined by taking aliquots of the cultures at different time-points and plating them on LB plates.

One of the physiological functions of FIS apparently is to allow very fast cellular growth.

\section{Discussion}

About nine years ago, Lee et al. [14] suggested that $t u f B$, although not essential for bacterial growth, 'might be required for certain rare growth conditions, such as rapid shift to fast growth conditions. If this were the principal need for tufB, then a mechanism might have evolved for the maintenance, during periods when it is not required, of a gene that is only occasionally essential for maximal growth. One way to preserve such a gene might be to place it in an operon with other essential genes, such as tRNA structural genes'. Although this may not be the only raison d'être of tufB, the foresight of these authors has come true in the sense that the thrU(tufB) operon is one of presumably many stable RNA operons, the transcription of which is stimulated by a common trans-activation mechanism permitting very fast growth. The $E$. coli protein FIS, here shown to bind to cis-acting regions upstream of at least three stable RNA promoters, plays a dominant role in this trans-activation. When stationary fis $^{+}$cells are suspended in fresh medium, growth reinitiates and soon accelerates to high rates (faster than 2.3 doublings/h) under favourable nutritional conditions (Fig. 9), thanks to FIS-dependent trans-activation of stable RNA operons (Fig. 8). Cells unable to produce FIS can compensate for the lack of the trans-activation system by relaxing the repressive system but this relaxation enables them to grow at moderate rates only [27].

Obviously, the function of FIS is not restricted to mediating fast cellular growth. Besides its role in sitespecific recombination [48-53], it contributes to finetuning of growth by counteracting repression of stable RNA synthesis through trans-activation. Moreover, although more experimental data are needed, the experimental results obtained so far suggest that the regu- lation of de novo synthesis of FIS is a basic element of growth control. It will be a matter of great interest to see, whether the synthesis of FIS responds to nutritional signals and if so, what is the underlying mechanism.

The dispensability of tuf $B$ for growth has raised the question whether tufA-defective cells, carrying an intact $t u f B$, are able to survive. The inactivation studies described in the present paper suggest that they cannot. It may be emphasized, however, that the lethal effect becomes apparent under strong selection pressure exerted on Mu-infected cells in the presence of kirromycin $[39,40]$. $\mathrm{Mu}$ infection may have increased the number of FIS binding sites within the cell, thus reducing the number of FIS molecules available for binding the UASs of stable RNA operons. Limited availability of EF-Tu may have conflicted with replenishment of FIS under the conditions of the experiment. The complementation studies illustrated in Fig. 2 indicate indeed that the intracellular EF-Tu then becomes limiting. This may be ascribed to the presence of kirromycin which causes a trail of immobilized ribosomes on the mRNA and depletion of EF-Tu. GTP. Wild-type EF-Tu will become stuck on these ribosomes and kirromycin resistant EF-Tu - GTP will be converted to EF-Tu - GDP during a non-productive interaction with these ribosomes. Outgrowth of cells in colonies strongly depends on FIS (Fig. 7), the synthesis of which is impeded by EF-Tu - GTP depletion. This interpretation is in accordance with our observation (Table II) that colony formation does occur, albeit strongly retarded, upon transformation with the plasmid carrying the $\operatorname{thr} U(t u f B)$ operon. The FIS binding sites on this multicopy plasmid may then compete with the sites on $\mathrm{Mu}$.

The question whether tufA is essential or dispensable for growth thus remains essentially unanswered. Future studies with Mu may be considered using FIS overproducing cells. Inactivation of tufA by a transposon or by amber mutations may also be more informative in this respect.

\section{Acknowledgements}

The plasmids containing the UAS derived from the $\operatorname{rrn} B, \operatorname{tyr} T$ and the $\operatorname{thr} U(\operatorname{tufB})$ operons and deletion derivatives thereof were generously donated by Drs. $R$. Gourse, A Travers and J. Van Delft, respectively. The strains MC 1000 and MC 1000-Fis 767 from the laboratory of Johnson were kindly provided by Dr. P. Van de Putte. The valuable help and suggestions of Drs. N. Goosen and P. Van de Putte are gratefully acknowledged. The investigation was supported in part by the Commission of the European Communities, Biotechnology Action Programme (BAP), Directorate-General 'Science, Research and Development', Brussels. L.N. was the recipient of a long-term EMBO fellowship. 


\section{References}

1 Miller, D.L., Weissbach, H. (1977) in Nucleic acids-protein recognition (Vogel, H.J., ed.), pp. 409-430, Academic Press, New York.

2 Kaziro, Y (1978) Biochim. Biophys. Acta 505, 95-127.

3 Pingoud, A., Urbanke, C., Krauss, G., Peters, F. and Maass, G. (1977) Eur. J. Biochem. 78, 403-409.

4 Ofengand, J. (1980) in Ribosomes, Structure, Function and Genetics (Chambliss, G., Raven, G.R., Davies, J., Davis, K., Kahan, L. and Nomura, M., eds.), pp. 479-529, University Park Press, Baltimore.

5 Hopfield, J.J. (1974) Proc. Natl. Acad. Sci. USA 71, 4135-4139.

6 Ninio, J. (1974) J. Mol. Biol. 84, 297-313.

7 Thompson, R.C. and Karim, A.M. (1982) Proc. Natl. Acad. Sci. USA 79, 4922-4926.

8 Thompson, R.C. and Dix, D. (1982) J. Biol. Chem. 257, 6677-6682.

9 Kurland, C.G. and Ehrenberg, M. (1985) Quant. Rev. Biophys. 18, 423-450.

10 An, G. and Friesen, J.D. (1980) Gene 12, 33-39.

11 Yokota, T., Sugisaki, H., Takanami, M. and Kaziro, Y. (1980) Gene 12, 25-31.

12 Yamamoto, M. and Nomura, M. (1979) J. Bacteriol. 137, 584-594.

13 An, G. and Friesen, J.D. (1980) J. Bacteriol. 144, 904-916.

14 Lee, J.S., An, G., Friesen, J.D. and Fiil, N.P. (1981) Cell 25, 251-258.

15 Hudson, L., Rossi, J. and Landy, A. (1981) Nature 294, 422-427.

16 Miyajima, A., Shibuya, M., Kuchino, Y. and Kaziro, Y. (1981) Mol. Gen. Genet. 183, 13-19.

17 Duester, G., Elford, R.M. and Holmes, W.M. (1982) Cell 30, 855-864.

18 Skjold, A.C., Juarez, H. and Hedgcoth, C. (1973) J. Bacteriol. 115, 177-187.

19 Baracchini, E. and Bremer, H. (1988) J. Biol. Chem. 263, 25972602.

20 Ikemura, T. and Dahlberg, J. (1973) J. Biol. Chem. 248, 5033-5041.

21 Nomura, M., Gourse, R.L. and Baugham, G. (1984) Ann. Rev. Biochem. 53, 75-117.

22 Lindahl, L. and Zengel, J.M. (1986) Ann. Rev. Genet. 20, 297-326.

23 Jinks-Robertson, S. and Nomura, M. (1987) in Escherichia coli and Salmonella typhimurium. Cellular and molecular biology (Neidhardt, F.C., Ingraham, J.L., Magasanik, B., Brooks Low, K. and Schaechter, M., eds.), Vol. 2, pp. 1358-1385, Am. Soc. Microbiol., Washington, D.C.

24 Cashel, M. and Rudd, K.E. (1987) in Escherichia coli and Salmonella typhimurium. Cellular and molecular biology (Neidhardt, F.C., Ingraham, J.L., Magasanik, B., Brooks Low, K. and Schaechter, M., eds.), Vol. 2, pp. 1410-1438, Am. Soc. Microbiol. Washington, D.C.

25 Gallant, J.A. (1979) Ann. Rev. Genet. 13, 393-415.

26 Lamond, A.J. and Travers, A.A. (1985) Cell 41, 6-8.

27 Nilsson, L., Vanet, A., Vijgenboom, E. and Bosch, L. (1990), EMBO J. 9, 727-734.

28 Miller, J.H. (1972) Experiments in Molecular Genetics, Cold Spring Harbor Laboratories Press, NY.
29 Van Delft, J.H.M., Marinon, B., Schmidt, D.S. and Bosch, L. (1987) Nucl. Acids Res. 15, 9515-9530.

30 Adams, C.W. and Hatfield, G.W. (1984) J. Biol. Chem. 259, 7399-7403.

31 Jaskunas, S.R., Lindahl, L., Nomura, M. and Burgess, R.R. (1975) Nature 257, 458-462.

32 Jaskunas, S.R., Burgess, R.R. and Nomura, M. (1975) Proc. Natl. Acad. Sci. USA 72, 5036-5040.

33 Van Delft, J.H.M., Verbeek, H.M., De Jong, P.J., Schmidt, D.S., Talens, A. and Bosch, L. (1988) Eur. J. Biochem. 175, 355-362.

34 Lamond, A.J. and Travers, A.A. (1983) Nature 305, 248-250.

35 Bauer, B.F., Kas, E.G., Elford, R.M. and Holmes, W.M. (1988) Gene 63, 123-134.

36 Gourse, R.L., De Boer, H.A. and Nomura, M. (1986) Cell 44, 197-205.

37 Travers, A.A. (1984) Nucl. Acids Res. 12, 2605-2618.

38 Parmeggiani, A. and Sander, G. (1980) in Topics in antibiotic chemistry (Sammes, P.G., ed.), pp. 165-221, Vol. 5, Wiley, New York.

39 Bosch, L., Kraal, B., Van der Meide, P.H., Duisterwinkel, F.J. and Van Noort, J.M. (1983) Progr. Nucl. Acids Res. Molec. Biol. 30, 91-125.

40 Vijgenboom, E. and Bosch, L. (9187) Biochimie 69, 1021-1030.

41 Van de Klundert, J.A.M., Van der Meide, P.H., Van de Putte, P. and Bosch, L. (1978) Proc. Natl. Acad. Sci. USA 75, 4470-4473.

42 Vijgenboom, E. (1989) PhD Thesis, Leiden University, The Netherlands.

43 Vijgenboom, E., Nilsson, L., Talens, A. and Bosch, L. (1989) Life Sci. 165, 57-65.

44 Vijgenboom, E., Nilsson, L. and Bosch, L. (1988) Nucl. Acids Res. 16, 10183-10197.

45 Hochschild, A. and Ptashne, M. (1988) Nature 336, 353-357.

46 Johnson, R.C., Ball, C.A., Pfeffer, D. and Simon, M.I. (1988) Proc. Natl. Acad. Sci. USA 85, 3484-3488.

47 Koch, C. (1988) PhD Thesis, Freie Universität, Berlin, Germany

48 Kahmann, R., Rudt, F., Koch, C. and Mertens, G. (1985) Cell 41 , 771-780.

49 Johnson, R.C. and Simon, M.I. (1985) Cell 41, 781-791.

50 Huber, H.E., Iida, S., Arber, W. and Bickle, T.A. (1985) Proc. Natl. Acad. Sci. USA 82, 3766-3780.

51 Koch, C. and Kahmann, R. (1986) J. Biol. Chem. 261, 1567315678.

52 Johnson, R.C., Bruist, M.F. and Simon, M.I. (1986) Cell 46 531-539.

53 Haffter, P. and Bickle, T.A. (1987) J. Mol. Biol. 198, 579-587.

$54 \mathrm{Li}$, S.C., Squires, C.L. and Squires, C. (1984) Cell 38, 851-860.

55 Thompson, J.F., Moitoso de Vargos, L., Koch, C., Kahmann, R and Landy, A. (1987) Cell 50, 901-908.

56 Van der Meide, P.H., Vijgenboom, E., Talens, A. and Bosch, L (1983) Eur. J. Biochem. 130, 397-407.

57 Van der Meide, P.H., Kastelein, R.A., Vijgenboom, E. and Bosch L. (1983) Eur. J. Biochem. 130, 409-417. 